\title{
Roles of polyurethane foam in aerobic moving and fixed bed
}

\section{bioreactors}

\section{Wenshan Guo ${ }^{\mathrm{a}}$, Huu-Hao Ngo ${ }^{\mathrm{a}^{*}}$, Fonny Dharmawan ${ }^{\mathrm{a}}$ and Carolyn Gay \\ Palmer $^{b}$}

${ }^{a}$ School of Civil and Environmental Engineering, University of Technology Sydney, Broadway, NSW 2007, Australia

${ }^{b}$ Institute of Water and Environmental Resource Management, University of Technology Sydney, Broadway, NSW 2007, Australia

* Correspondence author, Tel: +61-2-9514-1693, Fax: + 61-2-9514-2633, E-mail:h.ngo@uts.edu.au

\begin{abstract}
The aim of this study was to investigate the performance of sponge as an active mobile carrier for attached-growth biomass in three typical types of aerobic bioreactors to treat a high strength synthetic wastewater. The results show that sponge thickness deteriorated the organic and nutrient removal and $1 \mathrm{~cm}$ is the optimum thickness for fixed bed sponge biofilter (SBF). The sponge volume had significant impact on phosphorus removal rather than organic or nitrogen removal, and $20 \%$ volume of sponge could achieve 100\% T-P removal within 3 hours in a sponge batch reactor (SBR). When sponge coupled with submerged membrane bioreactor (SMBR), the single system show outstanding ammonium (100\% at filtration flux of 10 and 15 $\mathrm{L} / \mathrm{m}^{2} . \mathrm{h}$ ) and phosphorus (>91\% at all fluxes range) removal with optimum $\mathrm{pH}$ range of 6-7.
\end{abstract}


Keywords: Sponge-membrane bioreactor; Sponge batch reactor; Sponge biofilter; Biological organic and nutrient removal; Wastewater treatment

\section{Introduction}

As eutrophication of aquatic environment caused by nitrogen and phosphorus present in discharged effluent has become an unavoidable concern, the development of cost-effective and efficient biological nutrient removal (BNR) technology for wastewater treatment is highly promising to satisfy the stringent discharge standard (Ahmed et al., 2007; Li et al., 2003). Among numerous BNR systems, two configurations of bioreactors have been drawn a lot of attention in terms of achieving simultaneous nitrogen, phosphorus and carbon removal. The first one is attached biofilm reactor which involves attach growth on the inner and outer surfaces of small carriers mobilized in suspension either pneumatically or mechanically (moving bed biofilm reactor (MBBR), also called suspended carrier reactor), or immobilized in biofilter (fixed-bed biofilm reactor (FBBR)). The other one is aerated membrane bioreactor (MBR) coupled with chemical treatment process such as coagulation and adsorption, or be associated with sequential anoxic/anaerobic reactors for denitrification (Ngo et al., 2008).

Fixed-bed biofilm reactors are one of the extensively used systems in the removal of organic pollutants from wastewaters because of their simple mechanical configuration, enduring high organic loading rate, low-energy requirements and operating costs (Borghei et al., 2008; Leitão and Rodrigues, 1996). On the other hand, moving-bed biofilm processes have proved to be very reliable for nitrogen removal because of the high volumetric loading rates and the low solids build-up in the reactor. 
MBBRs simply allow separation of the treated water from the biomass-containing carriers, while excess biomass is sloughed off the biofilm and leaves the reactor with the effluent (Gapes and Keller, 2009). Chen et al. (2008) demonstrated a MBBR with an anaerobic-aerobic arrangement to treat landfill leachate using bio-carriers made of high density polyethylene. The anaerobic reactor played the most important role in the removal of COD (92-95\% at organic loading rate of $4.08-15.70 \mathrm{kgCOD} / \mathrm{m}^{3}$.d) due to methanogenesis, and the aerobic MBBR acted as the main undertaker for the $\mathrm{NH}_{4}-\mathrm{N}$ removal (>97\% at its HRT more than 1.25 days). Wang et al. (2006) also examined a combined chemical precipitation and MBBR system for municipal wastewater treatment. They reported that about $89.9 \%$ of total nitrogen $(\mathrm{T}-\mathrm{N})$ removal efficiency could be achieved through simultaneous nitrification and denitrification (SND) at dissolved oxygen (DO) concentration around $2 \mathrm{mg} / \mathrm{L}$. Overall, the main merits of MBBR systems can be summarized as follows (Gapes and Keller, 2009; Lee et al., 2006):

(i) simplicity, low space requirement and no sludge separation requirement for effective operation (advantages over activated sludge);

(ii) low headloss, no filter-bed channeling (i.e. all the bioreactor volume is used) and no need for periodic backwashing (advantages over fixed-bed biofilm reactors/biofilters or trickling filters);

(iii) large surface area for colonization and high specific biomass activity results in high resistance to overloading and toxic compounds;

(iv) protection of slow growing microorganisms from excessive abrasive removal (advantage over turbulent reactor biofilm systems such as fluidized beds);

(v) versatility; ability for retrofitting into existing tank volumes and addition to existing treatment systems to improve overall performance. 
Besides its compactness and complete solid-liquid separation, MBRs offer many advantages over the conventional activate sludge processes. However, although almost complete nitrification can be achieved in aerobic MBRs, denitrification always requires the addition of an anaerobic tank prior to the aeration tank with conventional recycle (Gander et al., 2000). Moreover, the concept of simultaneous phosphorus and nitrogen removal significantly depreciated the most favorable characteristics of long sludge retention time (SRT) control in MBR. Therefore, to solve the problem, various designs of treatment process associated with aerobic MBR have been reported. Ahmed et al. (2007) investigated the effects of internal recycling rate on nutrients removal in a sequential anoxic/anaerobic membrane bioreactor (SAM). Above $98 \%$ COD, $68 \%$ nitrogen and $55 \%$ phosphorus were removed when the internal recycling rate was 2.5 times of influent flow. Yuan et al. (2008) developed an innovative anoxic and anaerobic membrane bioreactor (AAAM) process to enhance biological nutrient removal. The results showed that COD removal efficiency was high and stable (>93\%) while nitrogen and phosphorus removal also attained high treatment levels $(64.7 \%$ and $94.1 \%$ respectively). The performance of a sequencing batch membrane bioreactor (SBMBR) for enhancing nitrogen and phosphorus removal was reported by Zhang et al. (2006). Through sequential operation of a MBR in alternating aerobic and anoxic/anaerobic condition, both of the ammonium nitrogen and total phosphorus removals of the SBMBR were maintained approximately $90 \%$.

To further solve the poor settling problem of MBBR, improve the organic and nutrient removal and reduce membrane fouling, MBR in conjunction with MBBR has been studied. Lee at al. (2006) found out that membrane-coupled moving bed biofilm 
reactor (M-CMBBR) had much lower biofouling rate than a conventional MBR when using activated carbon coated polyurethane cubes as attached growth media. Yang et al. (2009) compared the treatment capacity of a moving bed membrane bioreactor (MBMBR) with a conventional MBR. By using nonwoven carriers, the MBMBR system demonstrated good performance on nitrogen removal at different COD/TN ratios of 8.9-22.1. The specific oxygen uptake rate (SOUR) test showed that the biofilm had a better microbial activity than an activated sludge. Leiknes and Ødegaard (2007) also indicated when using high-density polyethylene material shaped as small cylinders as biofilm carriers, the MBBR reactor with a submerged MBR could achieve high sustainable filtration flux about $50 \mathrm{~L} / \mathrm{m}^{2} . \mathrm{h}$ at volumetric loading rates of 2-8 $\mathrm{kgCOD} / \mathrm{m}^{3} . \mathrm{d}$ and HRTs up to 4 hours.

Among various membrane-coupled MBBRs, bioreactors using polyurethane foam (sponge) for microbial immobilization have called new attention in order to simultaneously remove organic and nutrients in wastewater. As an ideal attached growth media, sponge not only can act as a mobile carrier for active biomass, but also can reduce the cake layers formed on the surface of membrane and retain microorganisms by incorporating a hybrid growth system (both their attached and suspended growth) (Ngo et al., 2006; Psoch and Schiewer, 2006). Deguchi and Kashiwaya (1994) have reported that the nitrification and denitrification rate coefficients of a sponge suspended biological growth reactor were 1.5 and 1.6 times respectively higher than the coefficients of conventional activated sludge reactor. However, for better understanding the role of sponge playing in bioreactors, more aspects of sponge need to be revealed. 
The purpose of this study was to investigate the performance of sponge as an active mobile carrier for attached-growth biomass in three typical types of aerobic bioreactors to treat a high strength synthetic wastewater. The systems were evaluated with different sponge configurations in terms of simultaneously organic, nitrogen and phosphorus removal: (1) the effect of sponge thickness on sponge biofilter (SBF) using low-dense sponge (S45R) and high-dense sponge (S90R); (2) the effect of sponge volume on sponge batch reactor (SBR) using low-dense sponge (S45R) and high-dense sponge (S90R), and (3) the effects of filtration rate and $\mathrm{pH}$ on spongesubmerged membrane bioreactor (SSMBR) using intermediate-dense sponge S60R.

\section{Materials and Methods}

\subsection{Wastewater and sponge}

A synthetic wastewater was used to simulate high strength domestic wastewater (just after primary treatment process). The synthetic wastewater contains glucose, ammonium sulfate, potassium dihydrogen orthophosphate and trace nutrients, which has dissolved organic carbon (DOC) of $135-160 \mathrm{mg} / \mathrm{L}$, COD of 350-400 mg/L, total nitrogen $(\mathrm{T}-\mathrm{N})$ of $17-20 \mathrm{mg} / \mathrm{L}$ and total phosphorus $(\mathrm{T}-\mathrm{P})$ of $3.6-4.0 \mathrm{mg} / \mathrm{L} . \mathrm{NaHCO}_{3}$ or $\mathrm{H}_{2} \mathrm{SO}_{4}$ were used to adjust $\mathrm{pH}$ in SMBR reactor to a constant value of 7 . Different pore sizes of reticulated polyester urethane sponge (S45R, S60R and S90R) from Joyce Foam Products, Australia, were used in this study. Table 1 gives the characterization of three different sizes of sponges. Sponge was cut in shape and acclimatized to wastewater before use.

Table 1

Characterization the different pore sizes of sponges 


\subsection{Experimental set-up}

Sponge biofilter $(S B F)$ A cylindrical column (19 cm height and $3 \mathrm{~cm}$ diameter) and a storage tank were used to treat $2 \mathrm{~L}$ wastewater (COD loading of $0.4 \mathrm{~kg} / \mathrm{m}^{3} . \mathrm{d}$ ) per day. Single piece of sponge (non-acclimatized) was cut to fit the bottom of the column and wastewater was pumped upward through the column and back to the storage tank (100\% recycling). The flow rate was set at $20 \mathrm{~mL} / \mathrm{min}$ in all the cases. The system was mainly used to examine the effect of sponge thickness and no sludge seeding performed in the SBF.

Sponge batch reactor (SBR) The bioreactor was equipped air diffuser and the air bubbles helped in supplying oxygen to the microbial mass for biological activity as well as mixing the sponge. $4 \mathrm{~L}$ wastewater was treated each time with the aeration rate of $8 \mathrm{~L} / \mathrm{min}$ and hydraulic retention time (HRT) of 8 hours. The predetermined volume of acclimatized sponge cubes $(10 \times 10 \times 10 \mathrm{~mm})$ were added directly into the reactor during the experiments. The function of the system was to test the effect of sponge volume.

Sponge-submerged membrane bioreactor (SSMBR) A polyethylene hollow fiber membrane module was used with the pore size of $0.1 \mu \mathrm{m}$ and surface area of $0.195 \mathrm{~m}^{2}$ (Mitsubishi-Rayon, Japan). The schematic diagram of the SSMBR is shown in previous research paper (Ngo et al., 2008). The effective volume of the bioreactor was $8 \mathrm{~L}$ with a MLSS of $10 \mathrm{~g} / \mathrm{L}$. Synthetic wastewater was pumped into the reactor using a feeding pump to control the feed rate while the effluent flow rate was controlled by a suction pump. Level sensor was used to control the wastewater volume in the reactor. A pressure gauge was used to measure the transmembrane pressure (TMP) 
and a soaker hose air diffuser was used to maintain a high air flow rate (3.69 $\mathrm{m}^{3} / \mathrm{m}^{2}$ (membrane area).h). The SSMBR was filled with sludge from a local Wastewater Treatment Plant and acclimatized to synthetic wastewater. Sponge volume fraction of $10 \%$ (bioreactor volume) was employed in this study according to previous research work (Ngo et al., 2008). The effects of filtration rate and $\mathrm{pH}$ were evaluated using this system.

\subsection{Analysis}

DOC of the influent and effluent was measured using the Analytikjena Multi N/C 2000. The analysis of COD and the measuring of mixed liquor suspended solids (MLSS) and biomass (monitored as mixed liquor volatile suspended solids, MLVSS) were according to Standard Methods (APHA, 1998). For measuring MLSS and biomass, three samples were taken each time and the average values were then calculated. $\mathrm{NH}_{4}-\mathrm{N}, \mathrm{NO}_{3}-\mathrm{N}, \mathrm{NO}_{2}-\mathrm{N}, \mathrm{T}-\mathrm{N}$ and $\mathrm{T}-\mathrm{P}$ were measured by photometric method called Spectroquant ${ }^{\circledR}$ Cell Test (NOVA 60, Merck).

\section{Results and Discussion}

\subsection{Effect of sponge thickness}

The previous study by Uemura et al. (2002) reported that the surface of the sponge biofilm was kept aerobically with high dissolved oxygen (DO) level. However, a distinctive DO gradient occurred along the sponge-inward depth, resulting in anaerobic conditions at deep inside portions of the sponge, which allowed denitrification happening in traditional way. Thus, three different thickness of sponges (1, 2 and $3 \mathrm{~cm}$ respectively) were compared using sponge biofilter (SBF) in order to examine whether the sponge thickness governs the performance of sponge. After 14 
days of inoculating sponge in the column, the organic and nutrient removal efficiencies of different thickness sponges were listed in Table 2. The mechanism of phosphorus removal in SBF was mainly due to uptake of phosphate by biomass growth. To some extend, it also could be removed by the phosphate accumulating organisms (PAOs) under the aerobic condition of the biofilter. During the experimental period, as the biomass produced could attach on the void of the sponge and there was only little excess biomass leaving the biofilter, the steady performance of T-P removal could be achieved in this system. In addition, it was found that both of organic and nutrient removal decreased with the increase of sponge thickness. For DOC removal, the removal efficiencies of S45R and S90R dropped $15 \%$ with $3 \mathrm{~cm}$ thickness of the sponge, while there were only slight changes in DOC removal efficiencies of 1 and $2 \mathrm{~cm}$ sponges. As the $\mathrm{NO}_{3}-\mathrm{N}$ and $\mathrm{NO}_{2}-\mathrm{N}$ concentrations in the effluent were less than 0.5 and $0.01 \mathrm{mg} / \mathrm{L}$ respectively, it demonstrated that the sponge itself has a function of simultaneous nitrification and denitrification (SND). This phenomenon was also verified the decreasing DO gradient occurring inside of the sponge cubes. The $1 \mathrm{~cm}$ sponge exhibited the best T-N and T-P removal $(39.9 \%$ and $61.0 \%$ for $\mathrm{S} 45 \mathrm{R}$ and $51.7 \%$ and $89.1 \%$ for S90R, respectively) compared to 2 and $3 \mathrm{~cm}$ sponges, which indicated there is an optimum thickness for active biomass working on and inside the sponge. Moreover, it could be seen visually that a thin layer of biofilm formed faster on $1 \mathrm{~cm}$ sponge than those on 2 and $3 \mathrm{~cm}$ sponges. The biofilm was kept aerobically which might give $1 \mathrm{~cm}$ sponge better nutrient and organic removal. As a result, $1 \mathrm{~cm}$ sponge was selected to conduct further investigation. Besides, the higher removal efficiencies associated with dense sponge were due to the dense sponge could response to more microorganisms growth (the 
total biomass of S45R and S90R were $1.09 \mathrm{~g}_{\text {biomass }} / \mathrm{g}_{\text {sponge }}$ and $1.37 \mathrm{~g}_{\text {biomass }} / \mathrm{g}_{\text {sponge }}$ respectively).

Table 2

Organic and nutrient removal of sponge with different thickness $(\mathrm{COD} / \mathrm{TN}$ ratio $=20$; COD loading $=0.4 \mathrm{~kg} / \mathrm{m}^{3} . \mathrm{d}$, column cross area $=7 \mathrm{~cm}^{2}$, DOC $=135-160 \mathrm{mg} / \mathrm{L}, \mathrm{T}-\mathrm{N}$ $=17-20 \mathrm{mg} / \mathrm{L}$ and $\mathrm{T}-\mathrm{P}=3.6-4.0 \mathrm{mg} / \mathrm{L}$ )

\subsection{Effect of sponge volume}

Normally, biomass retaining on sponge in two different forms: the one is thickand-dense biofilm developed onto the sponge cube surfaces, and the other is deposited or entrapped forms in the interior void space of the sponge cubes (Araki, et al., 1999). Scanning electron microscope (SEM) photos of sponge surface (S90R) were taken before and after acclimatization. It was clearly illustrated that the clean sponge has lots of clear pores before acclimatization. However, after acclimatization, an obvious deposition of biomass on the sponge surface and inside the sponge pores indicating that the sponge acted as an ideal support for biofilm growth.

Acclimatized sponge cubes $(10 \times 10 \times 10 \mathrm{~mm})$ were used as moving bed media in sponge batch reactor (SBR). Fig.1 presents the $\mathrm{NH}_{4}-\mathrm{N}$, T-P and DOC concentrations during the batch tests. Since only a negligible amount of biomass detached from sponge during the experimental time, the T-P present in the wastewater could be removed by PAOs attached on sponge. The data also illustrated that the sponge volume played a significant role in phosphorus removal for high-dense sponge (S90R) rather than low-dense sponge (S45R). When the sponge volume increased from $10 \%$ to $20 \%$, the S90R sponge could enhance T-P removal up to $99 \%$ and $100 \%$ within short retention time (within 6 hours and 3 Hours respectively), while S45R sponge only could eliminate $68.7 \%$ and $69.2 \%$ within 8 hours (Table 3 ). Comparing to 
phosphorus removal, increase of the sponge volume had little influence on organic and total nitrogen removal. The DOC removals reached more than $92 \%$ in all cases. However, the low nitrogen removal ability was observed in the batch experiments (around 10\% for S45R sponge and 20-30\% for S90R). Since the DO concentration of $7 \pm 0.25 \mathrm{mg} / \mathrm{L}$ and $\mathrm{COD} / \mathrm{TN}$ ratio of 20 were applied to the reactor during the experiments, getting such low T-N removal efficiency was due to the low volume of sponge used which resulted in less nitrifiers supply. Therefore, the best way to improve the nitrification rate in sponge moving bed reactor is either using high volume of sponge or coupled with suspended growth.

Fig. 1. Profiles of $\mathrm{NH}_{4}-\mathrm{N}, \mathrm{T}-\mathrm{P}$ and DOC concentrations during 8 hour batch tests Table 3

Organic and nutrient removal efficiencies of sponge batch reactor $(\mathrm{COD} / \mathrm{TN}$ ratio $=$ $20 ; \mathrm{DO}=7 \pm 0.25 \mathrm{mg} / \mathrm{L}, \mathrm{DOC}=135-160 \mathrm{mg} / \mathrm{L}, \mathrm{T}-\mathrm{N}=17-20 \mathrm{mg} / \mathrm{L}$ and $\mathrm{T}-\mathrm{P}=3.6-4.0$ $\mathrm{mg} / \mathrm{L}$ )

\subsection{Effects of filtration rate and $\mathrm{pH}$}

To further improve nitrogen removal in sponge moving bed reactor, spongesubmerged membrane bioreactor (SSMBR) using intermediate-dense sponge S60R was evaluated. Three filtration fluxes $\left(10,15,20 \mathrm{~L} / \mathrm{m}^{2} . \mathrm{h}\right)$ were tested under $\mathrm{pH}$ values of $5,5.5,6,6.5,7,7.5$ and 8 . The MLSS of suspended growth was maintained at 10 $\mathrm{g} / \mathrm{L}$ and sponge volume of $10 \%$ was used. The $\mathrm{DOC}, \mathrm{NH}_{4}-\mathrm{N}$ and T-P were measured in terms of variation of filtration rate and $\mathrm{pH}$. The results showed that the organic removals were similar and could keep in excellent removal efficiencies (>96\%) when the filtration flux and $\mathrm{pH}$ varied in the range of $10-20 \mathrm{~L} / \mathrm{m}^{2} . \mathrm{h}$ and $5-8$ respectively. However, when $\mathrm{pH}$ reached to 8 , the trace nutrients uptake by biomass could be affected and the effluent of SSMBR inclined to have slightly pink color. Ammonium removal increased together with increase of $\mathrm{pH}$ value. At filtration rates of $10 \mathrm{~L} / \mathrm{m}^{2} . \mathrm{h}$ 
(HRT of 4.1 hours) and $15 \mathrm{~L} / \mathrm{m}^{2} . \mathrm{h}$ (HRT of 2.74 hours), $100 \%$ nitrification was obtained at $\mathrm{pH}$ range of 6.0 to 7.5 . Nevertheless, nitrification did not complete $(<99 \%)$ at filtration rate of $20 \mathrm{~L} / \mathrm{m}^{2} . \mathrm{h}$ because of short HRT (2.05 hours). Similarly, the T-P removal was also affected by HRT and $\mathrm{pH}$. The results indicated that longer HRT led to higher T-P reduction in SSMBR. Moreover, within the $\mathrm{pH}$ range of 5.5 to 7 , more than $91 \%$ of phosphorus could be removed biologically. However, when $\mathrm{pH}$ was over 7, the T-P removal declined significantly $(<90 \%)$. Therefore, the optimum $\mathrm{pH}$ range for simultaneously nitrogen and phosphorus removal was 6-7.0.

\section{Conclusions}

The study evaluated three different sponge systems and the findings exhibited the perfect thickness of sponge was found to be $1 \mathrm{~cm}$ which resulted in highest removals in organic and nutrients. Moreover, the sponge volume had significant influence on phosphorus removal than organic or nitrogen removal, and $10 \%$ and $20 \%$ of sponge could achieve $99.4 \%$ and $100 \%$ T-P removal within short retention during the batch tests. When sponge combined with SMBR, the single system showed excellent ammonium (100\% at filtration flux of 10 and $\left.15 \mathrm{~L} / \mathrm{m}^{2} . \mathrm{h}\right)$ and phosphorus (>91\% at all fluxes range) removal with optimum $\mathrm{pH}$ range of 6-7.

\section{Acknowledgment}

This research was funded by Australian Research Council (ARC) Industry Linkage Grant (LP0882089). The authors are also grateful for the support of UTS Chancellor's Postdoctoral Research Fellowship and UTS Early Career Researcher Grants.

\section{References}


Ahmed, Z., Lim B. R., Cho, J. Ahn, K. H., 2007. Effects of the internal recycling rate on biological nutrient removal and microbial community structure in a sequential anoxic/anaerobic membrane bioreactor. Bioprocess and Biosystems Engineering 30, 61-69.

APHA, AWWA and WEF, 1998. Standard methods for the examination of water and wastewater, $20^{\text {th }}$ ed., American Public Health Association, Washington, DC.

Araki, N., Ohashi, A., Machdar, I., Harada, H. (1999). Behaviors of nitrifiers in a novel biofilm reactor employing hanging sponge-cubes as attachment site. Water Science and Technology 39(7), 23-31.

Borghei, S. M., Sharbatmaleki, M., Pourrezaie, P., Borghei, G. (2008). Kinetics of organic removal in fixed-bed aerobic biological reactor. Bioresource Technology $99,1118-1124$.

Chen, S., Sun, D., Chung, J. S., 2008. Simultaneous removal of COD and ammonium from landfill leachate using an anaerobic moving-bed biofilm reactor system. Waste Management 28(2), 339-346.

Deguchi, H. and Kashiwaya, M., 1994. Study on nitrified liquor recycling process operations using polyurethane foam sponge cubes as a biomass support medium. Water Science and Technology 30(6), 143-149.

Gander. M., Jefferson, B., Judd, S., 2000. Aerobic MBRs for domestic wastewater treatment: a review with cost considerations. Separation and Purification Technology 18, 119-130.

Gapes, D. J. and Keller, J., 2009. Impact of oxygen mass transfer on nitrification reactions in suspended carrier reactor biofilms. Process Biochemistry 44, 43-53.

Lee, W. N., Kang, I. J., Lee, C. H., 2006. Factors affecting filtration characteristics in membrane-coupled moving bed biofilm reactor. Water Research 40, 1827-1835. 
Leiknes, T. and Ødegaard, H., 2007. The development of a biofilm membrane bioreactor. Desalination 202, 135-143.

Leitão, A., Rodrigues, A., 1996. Modeling of biodegradation/adsorption combined processes in fixed-bed biofilm reactors: Effects of the intraparticle convective flow. Chemical Engineering Science 51 (20), 4595-4604.

Li, J., Xing, X. H., Wang, B. Z., 2003. Characteristics of phosphorus removal from wastewater by biofilm sequencing batch reactor (SBR). Biochemical Engineering Journal 16, 279-285.

Ngo, H. H., Guo, W. S. and Xing, W., 2008. Evaluation of a novel sponge-submerged membrane bioreactor (SSMBR) for sustainable water reclamation. Bioresource Technology 99(7), 2429-2435.

Ngo, H. H., Nguyen, M. C., Sangvikar, N. G., Hoang, T. T. L. and Guo, W. S., 2006. Simple Approaches towards a Design of an Attached-Growth Sponge Bioreactor (AGSB) for Wastewater Treatment and Reuse. Water Science and Technology 54(11-12), 191-197.

Psoch, C. and Schiewer, S., 2006. Direct filtration of natural and simulated river water with air sparging and sponge ball application for fouling control. Desalination 197, 190-204.

Uemura, S., Takahashi, K., Takaishi, A., Machdar, I., Ohashi, A., Harada, H. (2002). Removal of indigenous coliphages and fecal coliforms by a novel sewage treatment system consisting of UASB and DHS units. Water Science and Technology 46(11-12), 303-309.

Wang, X. J., Xia, S. Q., Chen, L., Zhao, J. F., Renault, N. J. and Chovelon, J. M., 2006. Nutrients removal from municipal wastewater by chemical precipitation in a moving bed biofilm reactor. Process Biochemistry 41, 824-828. 
Yang, S., Yang, F., Fu, Z. and Lei, R., 2009. Comparison between a moving bed membrane bioreactor and a conventional membrane bioreactor on organic carbon and nitrogen removal. Bioresource Technology 100, 2369-2374.

Yuan, L. M., Zhang, C. Y., Zhang, Y. Q., Ding, Y. and Xi, D. L., 2008. Biological nutrient removal using an alternating of anoxic and anaerobic membrane bioreactor (AAAM) process. Desalination 221, 566-575.

Zhang, H. M., Xiao, J. N., Cheng, Y. J., Liu, L. F., Zhang, X. W., Yang, F. L. 2006. Comparison between a sequencing batch membrane bioreactor and a conventional membrane bioreactor. Process Biochemistry 41, 87-95. 
Table 1

Characterization the different pore sizes of sponges

\begin{tabular}{ccccc}
\hline Sponge & $\begin{array}{c}\text { Density } \\
(\mathrm{kg} / \mathrm{m} 3)\end{array}$ & $\begin{array}{c}\text { Tensile } \\
\text { strength }(\mathrm{kPa})\end{array}$ & $\begin{array}{c}\text { Tear resistance } \\
(\mathrm{N} / \mathrm{m})\end{array}$ & $\begin{array}{c}\text { Cell count } \\
(\text { cells per 25 mm) }\end{array}$ \\
\hline $\mathrm{S}_{28-30} / 45 \mathrm{R}$ & 28 & 120 & 780 & $45 \pm 8$ \\
$\mathrm{~S}_{28-30} / 60 \mathrm{R}$ & 28 & 135 & 760 & $60 \pm 10$ \\
$\mathrm{~S}_{28-30} / 90 \mathrm{R}$ & 28 & 150 & 650 & $90 \pm 10$ \\
\hline
\end{tabular}


Table 2

Organic and nutrient removal of sponge with different thickness $(\mathrm{COD} / \mathrm{TN}$ ratio $=20$; COD loading $=0.4 \mathrm{~kg} / \mathrm{m}^{3} . \mathrm{d}$, column cross area $=7 \mathrm{~cm}^{2}$, DOC $=135-160 \mathrm{mg} / \mathrm{L}, \mathrm{T}-\mathrm{N}$ $=17-20 \mathrm{mg} / \mathrm{L}$ and $\mathrm{T}-\mathrm{P}=3.6-4.0 \mathrm{mg} / \mathrm{L}$ )

\begin{tabular}{ccccc}
\hline Sponge thickness & $\begin{array}{c}\text { DOC removal } \\
\text { efficiency (\%) }\end{array}$ & $\begin{array}{c}\text { T-N removal } \\
\text { efficiency (\%) }\end{array}$ & $\begin{array}{c}\text { T-P removal } \\
\text { efficiency (\%) }\end{array}$ \\
\hline \multirow{3}{*}{ S45R } & $1 \mathrm{~cm}$ & 75.8 & 39.9 & 61.0 \\
& $2 \mathrm{~cm}$ & 78.9 & 33.7 & 57.8 \\
& $3 \mathrm{~cm}$ & 60.4 & 16.4 & 43.4 \\
\hline \multirow{3}{*}{ S90R } & $1 \mathrm{~cm}$ & 76.9 & 51.7 & 89.1 \\
& $2 \mathrm{~cm}$ & 68.2 & 29.2 & 49.1 \\
& $3 \mathrm{~cm}$ & 50.5 & 19.7 & 39.4 \\
\hline
\end{tabular}


Table 3

Organic and nutrient removal efficiencies of sponge batch reactor $(\mathrm{COD} / \mathrm{TN}$ ratio $=$ $20 ; \mathrm{DO}=7 \pm 0.25 \mathrm{mg} / \mathrm{L}, \mathrm{DOC}=135-160 \mathrm{mg} / \mathrm{L}, \mathrm{T}-\mathrm{N}=17-20 \mathrm{mg} / \mathrm{L}$ and $\mathrm{T}-\mathrm{P}=3.6-4.0$ $\mathrm{mg} / \mathrm{L}$ )

\begin{tabular}{lcccc}
\hline \multicolumn{2}{c}{ Sponge volume } & $\begin{array}{c}\text { DOC removal } \\
\text { efficiency }(\%)\end{array}$ & $\begin{array}{c}\text { T-N removal } \\
\text { efficiency }(\%)\end{array}$ & $\begin{array}{c}\text { T-P removal } \\
\text { efficiency (\%) }\end{array}$ \\
\hline \multirow{2}{*}{ S45R } & $10 \%$ & 92.7 & 10.9 & 68.7 \\
& $20 \%$ & 93.3 & 13.1 & 69.2 \\
\hline \multirow{2}{*}{ S90R } & $10 \%$ & 93.5 & 22.2 & 99.4 \\
& $20 \%$ & 92.3 & 32.1 & 100 \\
\hline
\end{tabular}



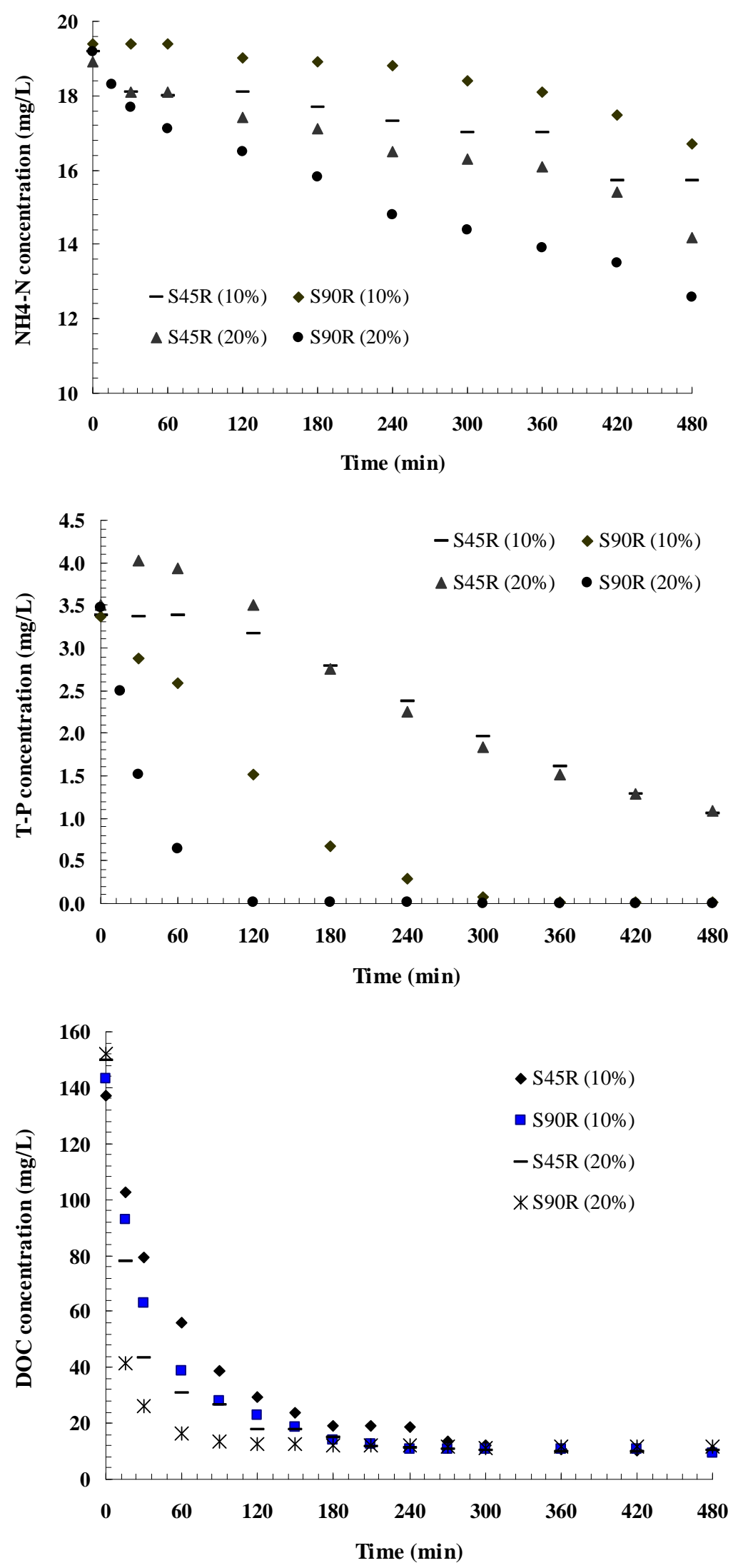

Fig. 1. Profiles of $\mathrm{NH}_{4}-\mathrm{N}, \mathrm{T}-\mathrm{P}$ and DOC concentrations during 8 hour batch tests 